\title{
Paluu oppimisesta opettamiseen ja kasvatus kohti aikuisuutta'
}

Kirsi Vaistela

Gert Biestan puheenvuoro ja hänen teoksensa "The Rediscovery of
Teaching" (Biesta 2017) pureutuivat kiinnostavalla ja puhuttelevalla
tavalla opettamisen, opettajan ja ylipäätän koko kasvatustehtävän mer-
kityksen ja tärkeyden löytämiseen uudelleen. Näkökulma tämän päiän
kouluinstituution ja koulutuksen rooliin yhteiskunnassa pohjaa kriitti-
seen kasvatusfilosofiaan. Pohjavireenä kulkee filosofian kielellä ilmaistuna
ajatus siitä, että kasvatuksen ydintehtävä nykyisessä, globaalien ekologis-
ten kriisien ja kapitalismin logiikan mukaan jäsenneltyjen elämänpiirien
maailmanajassa tulisi olla ihmisen maailmasuhteen ja vastuun uudelleen-
määrittely (esim. Saari, Jokisaari \& Värri 2014). Tässä tehtävässään kou-
luinstituutio ei Biestan mukaan ole onnistunut.
Opetusta on pidetty kasvatuksellisessa prosessissa kautta aikojen
enemmän tai vähemmän tärkeänä ja merkityksellisenä tekijänä. Se, mitä
kulloinkin on pidetty opetustehtävässä olennaisena ja mitä varten opetta-
minen on tärkeää, on vaihdellut aikansa olosuhteiden ja ihanteiden mu-
kaan. Aina on kuitenkin kyse ihmisyyden ennakoinnista: siitä, mikä on
se olio, jota kasvatus ja opetus koskevat. Kasvatusmaailman muuttumi-

1 Kommenttipuheenvuoro professori Gert Biestan keynote-luentoon "Why teaching matters: Education, social pedagogy and the school" Sosiaalipedagogiikan päivillä 28.-29.3.2019 Helsingissä. 
nen on välttämättä myös siis sen käsityksen muuttumista, keitä kasvatettavat ovat, keitä kasvatettavista halutaan tehdä sekä keiden yhteiskuntaa ja millaista yhteiskuntaa kasvatuksella pyritään edistämään. (Saari ym. 2014; Tomperi, Vuorikoski \& Kiilakoski 2005.)

Biesta nostaa esiin kiinnostavan dilemman, joka liittyy nykyiseen opetuksesta käytävään keskusteluun. Hän sanoo, että "ne, jotka ovat kiinnostuneita opettamisesta, eivät ole todellisuudessa kiinnostuneita opiskelijoiden vapaudesta, ja ne, jotka ovat kiinnostuneita opiskelijoiden vapaudesta, näkevät opettamisen esteenä sille”. Tähän tilanteeseen Biesta etsii kolmatta vaihtoehtoa: sellaista, missä opettaminen tuotaisiin takaisin kasvatukseen. Opettamisella olisi tärkeä, jopa olennainen rooli kasvatustehtävässä, jonka tähtäimenä on inhimillinen vapaus, emansipaatio.

Ajattelen omakohtaisen opettajan urani ja tutkimustyöni kautta, että yhtenä esteenä Biestan tavoitteelle on se, että koulun kasvatustoimintaa, samoin kuin opettajankoulutusta, on pitkään ohjannut yksilöpsykologinen ja järjestelmää palvelevan kasvatustieteen eetos. Tällä on nähdäkseni ollut kaksisuuntainen vaikutus. Ensinnäkin yhteiskunnalliset rakenteet ja vallan mekanismit jäävät näin helposti piiloon. Kun opetusta, oppilasta ja koulun kasvatustoimintaa tutkitaan ja katsellaan psykologian ja järjestelmää palvelevan kasvatustieteen kehikon kautta, alkavat itsestään selvinä pidetyt uskomusjärjestelmät vahvistua. Suunnitelmat, raportit ja tilastot tuottavat tehokkaan tuotantokoneiston tavoin toimivan koulutusjärjestelmän huoltamiseen sopivaa ja julkista päätöksentekoa sekä elinkeinoelämää hyödyttävää välineellistä tietoa. Kansallinen koulutusjärjestelmä ja sen mukana opettajan rooli ovat heiluneet innovaatiopolitiikan tuuliviirin puuskissa milloin minnekin. Koulutuksen kehittämispaineet ja opettajan roolin uudelleenmuotoilut ovat ainakin osittain olleet valtioiden välisen talouskilpailun ja tähän liittyvän retorisen kamppailun seurausta. (Ks. esim. Suoranta 2012.)

Toinen seikka liittyy oppimiskäsitykseen ja opettajan rooliin. Biesta nimittää nykyistä, konstruktivistisen oppimiskäsityksen aikakauttamme termillä "The Learnification of Education". Oppiminen on nostettu opettamisen edelle, ja koulun toiminta valjastettu yksinomaan yksilöllisen oppimisen edistämiseen. Oppilaista ja opiskelijoista puhutaan "oppijoina" ja kouluista "oppimisympäristöinä", opettajat taas ovat "oppimisen ohjaajia". Suomessa peruskouluissa pari vuotta sitten käyttöön otettu uusi perusopetuksen opetussuunnitelma vilisee "oppimaan oppimisen taitojen" tai "oppimisprosessin itseohjautuvuuden" ihanteita ja tavoitteita. Toisaalta on 
myös niin, että kun kasvatettava tulee määritellyksi psykologisin mittarein ns. normaaliuden - tai sen, mikä on keskivertoa - kautta, voidaan alkaa tehdä jakoja ja erittelyjä, "yksilöllisiä oppimispolkuja", jotka palvelevat opetuksen tehostamista.

Biesta myöntää, että yritys löytää ja elvyttää opettaminen ja opettajan merkitys tällä oppimisen aikakaudella on kuitenkin ongelmallinen. Ajatus vaikuttaa epätrendikkäältä erityisesti sen konservatiivisuuden vuoksi, sillä tällaiset yritykset on perusteltu usein kontrollin näkökulmasta. Parhaimpina ja tehokkaimpina opettajina pidetään niitä, jotka osaavat ohjata kasvatuksellisia prosesseja kohti ennalta määritettyjä oppimistuloksia ja identiteettejä, sellaisia kuten hyvät kansalaiset tai joustavat elinikäiset oppijat.

Myös tutkimuksen keinoin pyritään tuottamaan evidenssiä sille, mikä toimisi suhteessa näihin tavoitteisiin. On syntynyt "globaali kasvatuksen mittausteollisuus", joka innokkaasti mittaa, kontrolloi ja pyrkii osoittamaan, mikä systeemi tuottaa halutut lopputulokset ja mitkä koulu-uudistukset kasvattaisivat kansallista kilpailukykyämme. Ajatus kasvatuksesta kontrollina ja opettajista kontrollin edustajina liittyy myös huoleen, että nyky-yhteiskunta potisi jonkinlaista auktoriteetin puutetta. Opetus nähdään keskeisenä välineenä palauttaa tämä kadonnut auktoriteetti siinä samalla myös opettajalle. Näissä keskusteluissa unohdetaan usein kuitenkin se, että auktoriteetti on pohjimmiltaan suhteisiin perustuva asia. Se ei ole mitään sellaista, mitä joku henkilö voisi vain yksinkertaisesti asettaa toiseen henkilöön, kuten Biesta sanoo.

Miksi on sitten ongelmallista, että opetus ja kasvatus on sidottu nykyisin niin tiukasti yksilöllisen oppimisen ja suorittamisen ohjaamiseen, vertailevan edistyksen, kilpailun ja markkinahenkisen yhteiskuntamoraalin tarkoitusperiin? Kun kasvatustehtävässä keskitytään yksinomaan yksilön potentiaalin, oppimistulosten ja menestyksen tavoitteluun ja mittaamiseen, nähdään kasvatettavat subjektien sijaan objekteina, joita muokataan ja koulutetaan tiettyyn suuntaan. Kasvatustehtävä ja kasvatettava näyttäytyvät välineellisinä. (Esim. Horkheimer 2008.)

Myös se, että kasvatettava kohotetaan yksilönä kaiken keskipisteeksi, saa hänet pahimmillaan vetäytymään sisäänpäin, egoismiin, ja elämään vain itsensä kanssa ja itseään varten. Tämä estää häntä kasvamasta subjektiuteensa, täyteen aikuisuuteensa. "Aikuisuudella" tai täysikasvuisuudella Biesta ei tarkoita tässä yhteydessä kehityksellistä vaihetta tai kehityskaaren lopputulosta, vaan kyse on eräänlaisesta olemassaolon ominaisuudes- 
ta tai tavasta. Täysikasvuinen tapa olla olemassa ja elää subjektina on avoimuutta sille, kuka ja mitä toinen on. Se on elämistä "dialogin tilassa" toisen kanssa, toiseuden tunnustamista. Dialogin tilassa annamme sen, kuka ja mitä toinen on, koskettaa, puhutella ja opettaa meitä.

Eläminen subjektina tarkoittaa siksi, että sitoudumme jatkuvasti pohtimaan kysymystä siitä, onko se, mitä minä haluan, toivottavaa. Mitä haluni tarkoittaa oman elämäni kannalta, entä muiden ihmisten elämää tai koko planeettaa ajatellen? Aikuinen tapa olla olemassa tunnustaa, että maailma ei ole meidän tekemämme maailma eikä myöskään meidän käytettävissämme, eli me emme voi tehdä sillä, mitä me haluamme tai mistä tykkäämme. "Maailma" viittaa tässä sekä luonnolliseen että sosiaaliseen maailmaan, sekä asioiden että olentojen maailmaan. Tämänkaltainen ymmärrys on jännitteisessä suhteessa aikamme "impulssiyhteiskunnan" suureen periaatteeseen, missä vapautemme inhimillisinä subjekteina on pääasiassa käsitetty valinnanvapautena: vapautena tehdä, omistaa, olla, ostaa ja seurata halujamme.

Biesta haluaa nyt siis elvyttää opettamisen, ja kutsuu opettajia mukaan kasvatustehtävään, jonka tähtäimenä on inhimillinen vapaus, emansipaatio. Ei moralisoimaan vaan johdattamaan kasvatettavaa kohti "maailmakeskeisyyttä", maailmaan mutta ei sen keskipisteeksi. Pohtimaan kasvatettavan kanssa ei niinkään sitä, kuka minä olen, vaan sitä, miten minä olen, johdattamaan kasvatettavaa kohti täysikasvuista subjektiviteettiaan. Miksi tämä on sitten niin tärkeää erityisesti näinä aikoina? Aikamme länsimaisen ihmiskuvan perusta on syntynyt pitkälti uusliberalistisen hegemonian tuotoksena. Se perustuu individualismiin, ajatukseen yksilötason ensisijaisuudesta ja erityisyydestä sekä siihen, että "minä" on ympäristöstä riippumaton. Tämä ajattelu on johtanut solidaarisuusvajeeseen ja siihen, että sivuutamme toisten kokemukset. Sivuutamme myös muun ympäristön, ekologiat ja lajit, jotka kuitenkin ilmaston muuttuessa vaatisivat huomiomme. (Aaltola \& Keto 2017, 150, 175.) Jo nyt on nähtävissämme seuraukset esimerkiksi kasvavan rasismin ja lisääntyvien ympäristökatastrofien muodoissa. Viimeistään nyt olisi aika herätä ja huomata, että "kuulumme samaan elämän verkkoon, ja jos tuhoamme sitä, tuhoamme myös omaa elämäämme", kuten empatiatutkijat Elisa Aaltola ja Sami Keto $(2017,215)$ kirjoittavat. Tässä kasvatustehtävässä sosiaalipedagogisella ajattelulla ja työllä olisi oma, aivan erityinen asemansa koulun ja koulutuksen ympäristöissä toimiessa ja niiden toimintaa kehitettäessä. 


\section{LÄHTEET}

Aaltola, E. \& Keto, S. 2017. Empatia. Myötäelämisen tiede. Helsinki: Into Kustannus Oy.

Biesta, G. 2017. The Rediscovery of Teaching. New York: Routledge.

Horkheimer, M. 2008. Välineellisen järjen kritiikki. Tampere: Vastapaino.

Saari, A., Jokisaari, O-J. \& Värri, V-M. 2014. Johdanto. Kritiikin mahdollisuus. Teoksessa Saari, A., Jokisaari, O-J. \& Värri, V-M. (toim.) Ajan kasvatus. Kasvatusfilosofia aikalaiskritiikkinä. Tampere: Tampere University Press, 9-19.

Suoranta, J. 2012. Pikapiirto kasvatustieteellisen tutkimuksen sisäisestä työnjaosta. Tieteessä tapahtuu 1, 17-22.

Tomperi, T., Vuorikoski, M. \& Kiilakoski, T. 2005. Kenen kasvatus? Teoksessa Kiilakoski, T., Tomperi, T. \& Vuorikoski, M. (toim.) Kenen kasvatus? Kriittinen pedagogiikka ja toisinkasvatuksen mahdollisuus. Tampere: Vastapaino, 7-28. 
110 - Sosiaalipedagoginen aikakauskirja, vuosikirja 2019, vol. 20 